\title{
$J(\Theta)$
}

Received: 28.07.2019

\section{Additional Turkic and Tungusic Borrowings into Yukaghir IV}

\section{Yukagir Dilindeki Türkçe ve Tunguzca Alıntılara İlaveler IV}

\author{
Peter PIISPANEN \\ Stockholm University (Stockholm/Sweden) \\ E-mail: peter.piispanen@finska.su.se
}

Continuing on previous research, in this fourth part of a paper series, a total of sixteen newly found suggested borrowings from the Turkic, Tungusic and Mongolic languages into the Yukaghir languages and dialects of far northeastern Siberia are presented as loanword etymologies, as well as ten most tentative borrowing suggestions from the same sources, tentative only due to numerous semantic or phonological problems. The chronology of the totally twenty-six borrowing suggested is considered again to some degree, and solid phonological and semantic considerations are given for each suggestion, and other possible cognates or borrowings in the surrounding languages are also discussed. The results continue to highlight the extensive historical social contacts between the Yukaghir populations and surrounding tribes.

Key Words: Lexical borrowing, Tungusic, Turkic, Mongolic, Yukaghir, Nivkh, Russian. 


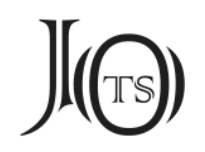

\section{Introduction}

This paper continues the research into newfound loanword etymologies for the Yukaghir languages and dialects of the far northeastern Siberia from Turkic, Tungusic and Mongolic languages, as well as, in a few cases from other languages, such as from Russian and, tentatively, from Nivkh or the Eskimo languages. In addition to numerous borrowing suggestions in every part of this paper series, some extra topic worthy of discussion and related to the topic of Yukaghir studies has been included. In the first paper, details regarding the chronology, phonology, prosody, estimated dating, and so on were presented (Piispanen 2018). In the second paper, the whole "Altaic" language hypothesis was discussed, and my own stance on it was made clear as it is relevant for properly understanding the argumentation made in this paper series (Piispanen 2019a and 2019b). In the third paper, which has two longer, separate parts, I suggested corrections to some older Yukaghir documentation, as well as summarized borrowings of grammatical markers (Piispanen 2019b: part 1), and the topic of Para-Yukaghir (Piispanen 2019b: part 2). In this fourth paper, I will discuss another tentative nominal derivational suffix, followed by quite a large number of new borrowing suggestions. This concludes the original publication plan, but if more research materials and results surface, further parts will likely be produced. ${ }^{1}$

\section{The nominal derivative suffix ${ }^{*}$-jə}

While Nikolaeva has presented a fairly exhaustive list of (one hundred and eighty-three historical) inflectional and derivational Yukaghir suffixes (Nikolaeva 2006: 79-83) there are actually more suffixes to add to these. Thus, before presenting the new borrowing suggestions, I will take the opportunity to discuss the nominal derivative suffix ${ }^{*}$-jə ( $>$ KY -ja \& TY -je). The suffix has been discussed elsewhere (Krejnovič 1958: 26-29; 1982: 90-91) but then as an imperfective participle suffix, which would mean that nouns with this suffix are all substantivized participles. I must hesitantly disagree with this take, and instead suggest that it

1 I wish to thank my colleagues Marko CRNOBRNJA, Juho PYSTYNEN, Mikhail ZHIVLOV, Alexander SAVELYEV, Alexander Vovin and Benjamin BRosig for their valuable and useful input on an earlier draft version of this paper. All remaining errors are, of course, my own. 


\section{J(৫)}

is simply yet another general nominal derivational suffix. While it is true that the suffix has, on occasion, been attached to imperfective forms, it has also, more often, been attached to the basic, underived verbal root to obtain the noun form. This suffix can be attested in at least twenty-six lexical examples, including:

PY *al'- > KY al'o:- 'melted' > KY al'o:ja 'ice-hole' (Nikolaeva 2006: 100);

PY *am- > KY amdə- 'to die' > KY amdija 'bedding' (Nikolaeva 2006: 102);

PY *anqa- > KY anyi:- 'to comb; to scratch, to scrape' > KY anyzja 'snowstorm' \& anyija 'comb' (Nikolaeva 2006: 109);

PY *čel- > KY čel- 'cold' > *čelja > KY če:d’a 'winter' (Nikolaeva 2006: 128);

PY *čoyo- > KY čoy- 'to cut'; TY čay- 'to cut; to break one's word' > KY čoyoja 'knife'; TY čoyoje (Nikolaeva 2006: 136);

TY enunne- 'thin' > TY enunnije "part of the skin which is too thin to use for clothing' (Nikolaeva 2006: 162);

PY *ire- > KY ige:- 'caught'; TY ige- 'to be tied; to be stuttering' (Kurilov 2001: 82) > KY ige:ja 'rope, belt'; TY igiije 'belt' (Kurilov 2001: 82; Nikolaeva 2006: 170);

PY *jö:- > KY jö:- ‘to see’; TY juo- > KY jö:ja ‘devil, evil spirit'; TY juoje ‘spiritassistant of a shaman' (Nikolaeva 2006: 191);

PY *jömkə- > KY jömga- 'to spin, to turn around' > KY jömgija 'whirlpool'; TY jömgije (Nikolaeva 2006: 193);

PY *kerpo- > KY kerpo- 'to wave, to flap, to swing, to sweep; to remove snow' $>$ KY kerpija ‘broom' (Nikolaeva 2006: 208);

PY *köntə- > KY pude:- 'to put down' > KY pudečiją 'murderer' (Nikolaeva 2006: 221);

PY *kude- > KY kude- 'to become, to begin; to turn into'; TY kure- 'to do, to act' > KY kudeja 'family, clan, ancestors; origin'; TY kurije ‘предок' (Kurilov 2001: 171; Nikolaeva 2006: 225);

PY *ley-> KY leyda- 'to eat (INTR)'; TY lewd'e- 'to eat' (Kurilov, G.N. 2001:217) $>$ KY lendija 'big old-style wooden spoon'; TY lewdii: 'fork' ( * *lewdije) (Nikolaeva 2006: 238); 


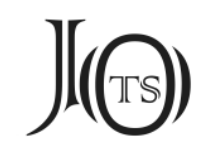

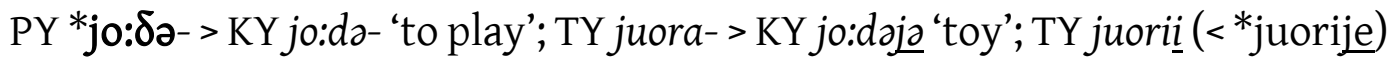
(Nikolaeva 2006: 246);

PY *löw > KY löudu:- 'to fall down' > KY lömdija 'precipice' (Nikolaeva 2006: 250)

PY *l'uk > KY juku- 'small, little' > KY jukuńe:ją 'small mouse' (Nikolaeva 2006: 252-253)

PY *memčə- > KY memžə- 'to flame, to blaze'; TY mömde- 'гореть ярко' (Kurilov 2001: 260) > KY mömžjja ‘flame'; TY mömdije ‘flame' (Kurilov 2001: 260; Nikolaeva 2006: 263);

PY *mumčə- > KY mumžə- 'to buzz, to hum; to drone' > KY mumžəja 'properller; weathercock' (Nikolaeva 2006: 280);

PY *ńatńə- > KY ńatńo- nutńz- 'to stick out; to stick to' > KY nutníija 'navel' (Nikolaeva 2006: 291);

PY *noy- > KY nojdi:- 'to be in wait for, to be on guard, to watch over; to keep (TR)' > KY nojdi:ja ‘servant' (Nikolaeva 2006: 305);

PY *ńöm- > KY mumžz- 'to get narrower' > KY mumžija 'narrowed place' (Nikolaeva 2006: 307);

PY *paj- > KY pajdu- 'to beat'; TY pajdu- 'бить, ударить во что-л.; лупить; сбивать что-л.' (Kurilov 2001: 362) > KY pajdujə 'shaman's drumstick'; TY pajdii 'орудие (доска с зубьями) для выколачивания песцового меха = board with

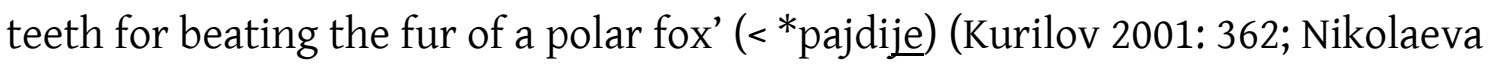
2006: 340-341);

PY *poj- > KY pejdə- 'to step on (TR)' > KY pejdija 'stairs; bridge' (Nikolaeva 2006: 355);

PY * porqa- > KY porqo:- 'crooked' > KY porqaja 'curved bank' (Nikolaeva 2006: $362)$;

PY *söy- > KY šgo- 'to enter; to fit in' > KY söge:ja 'pocket' (Nikolaeva 2006: 409); 


\section{J(৫)}

PY *uj- > KY uj- 'to work, to do' > KY u:jə 'wing'; TY uje 'крыло, крылья' (Kurilov 2001: 484; Nikolaeva 2006: 441);

PY *wele- > KY elo:- 'crooked' > KY elo:jə 'stick for driving a sledge' (Nikolaeva 2006: 455);

Also: TY ayarii- 'прятать; скрывать = to conceal'; to hide, to cover" > ayarije(y) 'туман; парок = fog; parka' (Kurilov 2001: 25-26); TY vajazaj- 'уплыть (по течению) = to float away' > vajayije 'течение = flow' (Kurilov 2001: 61), and many others.

In the above examples, all $\mathrm{KY}$ and $\mathrm{TY}$ roots having a root-final ${ }^{*}$-jo which are not representatives of this suffixation, have been excluded. In Tundra Yukaghir, for a few words, an irregular phonological change *-ije > -ii can seemingly be observed, which is very similar to the already known phonological change of ${ }^{*}$-ej > - $i$ : in TY (a semi-regular feature according to Nikolaeva, I. 2006:64). M. Zhivlov counter-suggested that such TY words may instead have been suffixed with the well-known PY nominal derivational suffix *:-i (Nikolaeva 2006: 80). However, it does not seem likely to me that the same root would have been suffixed with two very similar suffixes in Tundra and Kolyma Yukaghir, respectively. Rather, assuming uniformity, I believe that they were both suffixed with one historical suffix ${ }^{*}$-jo , which then developed irregularly only in a few words in TY ('to eat' and 'to play' above). In addition to the above, we may probably also assume the suffixed forms of: TY čanтіje “лабаз, кладовая на четырех столбах = shed for keeping food' (Kurilov 2001: 547; Nikolaeva 2006: 124) \& TY kedeje 'greater part of something' (Kurilov 2001: 176; Nikolaeva 2006: 207) from two unattested verbs or adjectives.

As evident above, this suffix is thus usually added to an adjective or verbal stem to create a noun, and it has been used at least since the time of Late ProtoYukaghir as it is widely attested in all branches of Yukaghir. While it may have been part of some grammatical descriptions for Yukaghir (such as the materials presented by Maslova), it can herewith also be added to the known, historical suffixes of Yukaghir. 


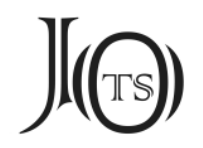

\section{New borrowings into Yukaghir}

Below I present sixteen new suggested Turkic, Tungusic and Mongolic borrowings into the Yukaghir languages and varieties.

New borrowing

Yakut etemet 'все в порядке, все благополучно = everything is good, all is well' (JRS 549), borrowed as: TK etem-göde 'winner of a sporting competition, lit. all-good man' (< göde 'man')(< ?*etemet-göde) (Nikolaeva 2006: 166).

Another unique TK compound (the rarity in itself suggesting borrowing), etem-göde, can be described as another Yakut borrowing. Only in Yakut, of all languages surrounding the Yukaghir languages, can a word of reasonable meaning and phonology be found for the first non-etymologized part of this compound. Phonologically speaking, the match of this suggestion is excellent, with the Yakut form having been truncated for use with this compound. There are numerous Yukaghir compounds containing -göde and that comes naturally for describing various types of men. It is possible that the word was originally *etemet-göde, directly after borrowing, but which was then shortened to etemgöde in rapid speech. No Late Proto-Yukaghir reconstruction is required for this root.

Yakut etemet is a term (for me of unknown etymology, but the ending of et would seem to be some sort of morphological marker, and the word has a decidedly Turkic feel to it) meaning that all is well, everything is good, and it is easy to see how that could have been transferred into Yukaghir as the winner of a sporting competition. The winner of several sporting events, the grand champion, is good at every event. In other words, an all-good man is the winner of a sporting competition. A possible comparandum is Ewen etenmej 'способный, способность сарасity, ability' (Robbek \& Robbek 2005: 350), which, if borrowed into Yukaghir would in this context have meant 'ability-man', but the similarity is likely coincidental only. 


\section{$J(\Theta)$}

New borrowing

Ewenki kēlči 'охотничья лыжа-волокуша (широкая короткая доска с загнутым спереди концом = hunting drag ski (wide short board with a curved end in front)' (Vasilevic 1958: 198), borrowed as: KY köliče 'ski' (Maslova 2003: 548).

The borrowed Yukaghir form has achieved prosodic validity (ending in an apparent nominal derivational suffix -če), but this correspondence, along a very limited attestation on the Yukaghir side, show that this indeed should be a borrowing. The origin of the Ewenki word is etymologically not completely clear as this is not the standard Ewenki word for 'skis', which is kinle (< Proto-Tungusic *künile 'skis', TMS 1396; EDAL 689). This Ewenki word (which carries a nominal derivational suffix -čī; Vasilevic 1958: 797), however, has a cognate in Negidal kēelči 'долбленая из лиственницы волокуша охотника = dug out larch of hunter's trap?', which suggests that the direction of borrowing for this word is Ewenki > Yukaghir. The semantic narrowing of the Ewenki meaning in Yukaghir would be quite expected of a borrowing (specific item > generic item). Another noteworthy thesis, pointed out by M. Crnobrnja, can be noted: since the Ewenki were historically extremely mobile, it is possible that this is instead a rare Yukaghir borrowing into Ewenki, that, in its turn, was borrowed further into Negidal from the Ewenki, i.e. Yukaghir > Ewenki > Negidal. While no exact parallels for this type of borrowing are known, it does remain within the realm of possibility; indeed, Yukaghir borrowings into Ewen/Ewenki/Yakut are probably a bit more common that commonly believed.

New borrowing

Rus. начет 'вид денежного взыскания' > Yakut nос̌оot 'убыток; убытки = damage, material losses', nočoottox ‘убыточный = unprofitable' (JRS 255), borrowed as: KD nočoči- 'to take the expense on oneself (Nikolaeva 2006: 304)(<*nočoti:-).

This unique and fairly interesting KD verb, attested nowhere else, is derived from a Yakut borrowing - as demonstrable both from a semantic and phonological perspective - and no Late Proto-Yukaghir reconstruction is therefore necessary. In Yakut, this noun can be used, for example, as kini nočookko kiirde 'he suffered a loss' and nočoottox terilte 'unprofitable enterprise', which is semantically 


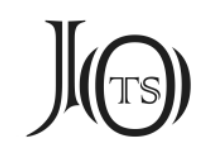

exactly what this likely recent borrowing into Yukaghir describes as a verb with 'to take the expense on oneself'. Indeed, the Yukaghir form is verbally suffixed, thus creating a verb from the Yakut noun. This borrowing most likely took place during the often intensive trading activities between Yakut merchants and Yukaghirs. The origin of the Yakut form, then, is Russian with a term pertaining to an early monetary penalty, which was used in local trade at the time (as mentioned by A. Savelyev).

The original borrowed form into KD was most likely *nočoti:-, which bears a Yukaghir causative transitive verbal suffix, -i:, directly attached to the borrowed root (Nikolaeva 2006: 80), and the following spontaneous palatalization in KD (that is, the change -ti:- >-či-) has numerous phonological parallels; cf. Rus. gostit', borrowed as: KD goči- 'to visit'; Rus. kolotit' (Nikolaeva 2006: 168), borrowed as KD koloči- 'to nail' (Nikolaeva 2006: 218); Rus. kroštit', borrowed as: KD kroči- 'to crumble' (Nikolaeva 2006: 224).

\footnotetext{
New borrowing

Rus. rol' 'роль = role, part, character', borrowed as: Yakut oruol 'роль = role', oruolaa'рассматривать; разглядывят кого-что-либо с подозрительным вниманием; изучающе = to consider; to be looking at someone with suspicious attention; studying' (JRS 278), borrowed as: TD oro:l 'nature; character, temper' (Nikolaeva 2006: 336).
}

This isolated TD word is another Yakut borrowing, which in its turn originates in a Russian word. This loanword etymology may be an entirely new one. In Yakut, an epenthetic root-initial vowel has been added with the borrowing of this word, which commonly occurs with $r$-initial borrowings. The same epenthetic vowel is found also in the Yukaghir form, which along with the non-palatalized word-final lateral as well as the long vowel, phonologically shows us that the word was borrowed from Yakut and not from Russian (thus adding to the list of known Yakut-intermediated Russian borrowings into Yukaghir presented elsewhere: Piispanen 2019a). While Yukaghir does have a nominal derivational suffix $-l$, the root-final $-l$ in Yukaghir here is the one retained from the Yakut form (Rus $-l$ ' > Yakut $-l$ ). 


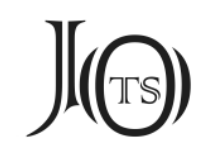

Semantically, the word means 'role', in all its meanings and functions, in both Russian and Yakut, and has come to describe the semantically connected concepts of a man's character, his temper or his very nature in Yukaghir. Indeed, the Yakut verbal form clearly pertains to studying someone's character, while the Russian word also means character. The nominal form of the Yakut word is used in examples such as: he plays his role/function well; you will play this part; party role. Data on the Yukaghir side is lacking, as this seems to be documented only in Jochelson's manuscript dictionary, but this is to be considered a certain borrowing.

New borrowing

Yakut yles- 'заказывать; уславливаться, договариваться = to order; to make arrangements, to negotiate', ylex ‘заказ; договор, уговор = order; contract, persuasion' (JRS 453), borrowed as: TY aalil 'заказ = order', TK alil, TY aalieče( $\eta)$ 'заказчик = person who gives orders, customer', TK a:lieče 'order', TY aalie- 'делать заказ (на что-либо) = to make an order (for something)', TK alie-, a:lie-, a:li- (Kurilov 2001: 19; Nikolaeva 2006: 100).

The Yukaghir forms are only documented in Tundra Yukaghir dialects, and are borrowings having been suffixed for various purposes. Semantically, all forms pertain to the semantically linked concepts of 'order, persuasion; to give orders; to persuade; customer, etc.'. The Yakut root is also borrowed into Ewenki as ulek 'заказ; уговор, условие = order; persuasion, condition' (borrowing noted in Vasilevič 1958: 441); the borrowed Ewenki form shows that the Pre-Yakut form used to be *ulek 'order', which was likely also the form separately borrowed into Yukaghir. The Yukaghir forms are suffixed as nominal derivatives (-l and - ̌̌e, respectively), with the bare root remaining a verb. Again, odd vocalic switches between $u l->$ al- are noted as with other borrowings of similar phonology (also cf. PFU *sula 'to melt' (UEW 450-451), cognate with PY *al'- > KY al'a:-, TY al'aa- 'to thaw', etc.; Nikolaeva 2006: 100).

New borrowing

Written Mongolian čürügü (nugusu(n)) ‘teal, lit. teal duck' (Lessing, F.D. 1960:210,596), etc. (VEWT 463; EDT 536), borrowed as: Yakut čörköj 'чирок = teal' (JRS 513), borrowed as: TY čuorqa 'гусь-гуменник = bean goose (Anser fabalis)'; TD čorхo-; TY čuorqijaa 'a lake in folklore, lit. bean goose lake' (Kurilov 1990: 332; 2001: 570; Nikolaeva 2006: 142). 


\section{J(৫)}

As Nikolaeva mentions, the Yukaghir word, found attested only in a few Tundra Yukaghir dialects, has an irregular long vowel in a closed syllable, and the reason for this phonological aberration of course being that the word originated recently as a borrowing from Yakut, which has different prosody and phonology. The Yakut word itself, then, should be an hitherto undiscovered Mongolic borrowing (see above), which herewith gets a loanword etymology, and it must have been borrowed from a Mongolic source still exhibiting a word-final $j$ at the time of borrowing. The Mongolic form is also found with Buryat šürxi 'teal' and Kalmuck čörkə ־̌̈rrga 'teal', which is the exact same bird as found in Yakut, thus relatively safely confirming the Mongolic borrowing in Yakut. However, it seems that a Proto-Mongolic root *čirökej 'a kind of duck' cannot be reconstructed due to limited attestation and indeed it is not to be found in Nugteren, H. 2011 either. M. Crnobrnja suggests to me that this root may be a wider Siberian Wanderwort, ultimately onomatopoetic, ${ }^{2}$ and has found its way only into a few of the Mongolic languages, possibly independently (B. Brosig suggests that hardly even a Central Proto-Mongolic form is reconstructible for these; the forms are only used attributively and are not morphologically transparent), as well as into a few other Siberian languages. Still, in this case, I suggest the ultimate origin of the Yakut (and Yukaghir) form specifically to be from Mongolic (by me assumed to be the so-called Written Mongolian variety) as suggested by the phonology.

Furthermore, the Mongolic borrowings are also found as Oyrat čüräkäj, Kazan šürügüj, etc. (according to VEWT 121), which again show the early word-final $-j$. The ending of the Yakut word, -rköj, is invalid in Yukaghir and so it is instead found a the completely regular and phonologically valid ending of -rqa -rqa (in Yukaghir a nominal derivational suffix; Nikolaeva 2006: 83). Still, the irregular long vowel in a long syllable, which likely originated due to word stress, clearly marks this as being a borrowed form, and indeed it is demonstrated here as such.

\footnotetext{
2 This ultimate origin of this root, as to language group, is therewith very uncertain, but is seems likely that it was, on occasion, locally suffixed in the languages into where it was borrowed from some neighboring language.
} 


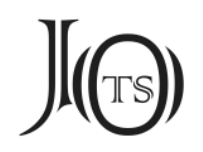

That we are dealing with a Wanderwort root is suggested also by the existence of this root in some of the Uralic languages (browsable in Vasmer's dictionary), as well as in Polish czyranka and Ukrainian чириця, чиренка, чирка 'teal'. The borrowing has undergone a semantic shift as to the species of bird described. The Mongolic and Yakut teal is a duck, while the Yukaghir bean goose is a goose. The birds, however, are fairly similar in appearance (both are gray and have colored heads), both exist in Yukaghir and Yakut lands, and it is understandable as to how the exact bird designated by this word could have changed as the word was borrowed.

New borrowing

Ewen eke: ‘старшая сестра, сестрица; тетя’ (Robbek \& Robbek 2005: 342), OR somewhat less likely Ewenki eke: eki: ( ekēkē) 'elder sister; aunt' 'старшая сестра, сестрица; тетя, тетюшка = elder sister; aunt' (TMS 2 443), borrowed as: TY eke: 'elder sister' (Nikolaeva 2006: 30).

This constitutes another kinship word borrowing. Ewen has two very similar words for 'elder sister', namely eke: and eken 'elder sister; aunt' (Robbek \& Robbek 2005:342). The former should be just a contracted form of the latter, and this latter form is likely also the one borrowed into Yukaghir. The word as such exists also in Ewenki eke: 'elder sister; aunt' \& ekin 'elder sister; aunt' (TMS 2 443), and a common derived root is found with Ewen ekedmer 'старше, старший = older' (Robbek \& Robbek 2005: 342) \& Ewenki ekindymer 'старше, старший = older' (Vasilevic 1958: 636), and in addition there are numerous other cognates to be found in the various Tungusic languages (including Solon, Negidal, Oroch, Udege, Ulcha, Orok, Nanai, Manchu and Jurchen), so the word is definitely originally Tungusic, which proves the direction of borrowing into Yukaghir.

Other relevant comparisons are to Proto-Turkic *eke 'older sister' (VEWT 38, ЭСТЯ 1 222-224, TMN 1 190, 2 91-92, EDT 100, 102, егоров 23) which, pointed out by M. Crnobrnja, is attested at least in Old Uyghur, Karakhanid, Turkmen and Chuvash (also as the derivative *egeči 'older sister'). I am unable to find this root in Yakut however, and so its presence in Yukaghir must be ascribed to Tungusic sources. J. PYSTYNEN suggested to add Ugric *äKз 'girl, daughter' to this comparison, but he also wisely suggests that too much confidence should not be put onto 


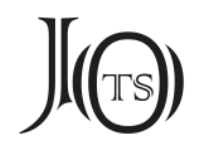

isolated comparisons of the \#ACA-type words for various relatives. Indeed, many of them appear to be nursery words, which puts all comparisons on a very shaky ground. So the relation between these aforementioned roots, if any, is unclear.

Previously, Nikolaeva connected Ewen eken 'elder sister' (TMS 2443 ) to the borrowed forms of TY ekya 'старшая сестра = elder sister' (Kurilov 2001: 592); TK ekye akye; TJ akye ekye 'elder sister; elder female cousin', ekeo- 'to be smb's elder sister' (Nikolaeva 2006: 154), but as the TK and TJ form ekye (a likely primary form after borrowing; *ekje < *ekee, the former possibly being a transcriptional artifact by some authors as Nikolaeva herself suggests) shows, a better comparison would be directly to Ewen eke: or, less likely, Ewenki eke: (see above). I therewith suggest that Nikolaeva's comparison should be superseded by this new etymological suggestion. Furthermore, the TMS compares these Tungusic words to Written Mongolian eke 'mother', etc. and there may be a connection, i.e. the Tungusic forms may be Mongolic borrowings.

New borrowing

Old Turkic čoðïn čoyïn čo(y) ğïn čo(y)g̈̈̈n 'bronze; cast-iron' (Clauson 1972: 403; Rybatzki 1999: 69) (borrowed as: Russian čugun 'cast-iron', borrowed as: Ewenki čugume ‘чугунный = cast-iron' (Vasilevič 1958: 635) \& Yakut čuguun 'cast-iron; pot' (JRS 513), borrowed as Yukaghir (*čo:(n)): TY čuo 'iron, metal'; TK t'uo, TJ čo, TD čo:, čo-, MO tče, KL čon- (< *čoyïn), MK tschón-, TK t'uod-a:ri: 'gun, lit. iron gun'; TD čuod-ari, čo:d-ari ‘+ pulse'; RS čod-arie, TY čuoraske 'boiler, lit. iron bowl'; TK t'uo-raske, TD čo-ruska, čo:x-suske, čo-ruske; TY čuon-mooje 'vice, pincers, lit. iron holder'; čuon-mayil 'chain-mail, lit. iron coat'; čuo-raske-lolyije 'spray from a boiler, lit. boiling from an iron bowl'; čuon-dawza 'frying-pan, lit. iron bowl', TD čuodarid-ayil' 'muzzle of a gun'; MK tschët-padánget 'lock' (Nikolaeva 2006: 135).

The common modern and historical word for iron in Yukaghir is an early Turkic borrowing meaning cast-iron. The Yukaghirs, prior to contact with the Russians, practically lacked any deeper technological knowledge, the use of most metals and any metallurgical skills, despite some documents hinting at ancient Yukaghir warriors carrying metallic breastplates. The same Turkic root, which exhibits numerous different spellings in Old Turkic, was - as evident from the phonology (čo(y)ğïn or čco(y)g̈̈̈n) and identical semantics (of cast-iron) - also borrowed, from a Turkic language using a plosive form, as Russian čugun, which was then subsequently borrowed as Ewenki čugume (where -me is a suffix according 


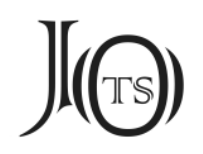

to Vasilevič 1958: 769). According to Clauson (1972: 403) and Rybatzki (1994: 221) the Old Turkic root originally meant not 'cast-iron', but 'copper' or 'bronze', and is supposed to be of Chinese origin. Räsänen notes in the VEWT a version that only has the first element *coy in the Altai languages, but this should not be the direct origin of the Yukaghir forms. The same Turkic root is also found widely attested in Yukaghir, with numerous compounds, although it is conspicuously missing in Kolyma Yukaghir. One might perhaps have expected a Russian source for this root into Yukaghir, but the phonology actually clearly shows that the donor language must have been a Turkic one, and then one not using the plosive form; the donor into Yukaghir should have been Turkic čoyïn which lacks a plosive, but again a contraction of, for example, Yakut čuguun is possible. The Russian and Ewenki forms also originate in borrowing from Turkic, but from a spoken and spelled variety having a plosive, and so we are dealing with two independent (groups) of borrowings from different Turkic sources, one having a plosive form, and the other not having the plosive at all.

Trouble-shooting the matter further, in theory, the Yukaghir root could have originated from a contracted form of Russian čugun, but this seems unlikely as the plosive is nowhere to be seen in Yukaghir, this is uncommon in Yukaghir, and there are no phonological traces of anything having been eliminated from the root, and, more importantly, there is a phonologically better alternative from a Turkic source. The inclusion of the old attested KL (\& MK) čon- was hesitantly given in the dictionary, but it is, in fact, the form phonologically closest to the original Turkic word as it still carried the original $-n$. Indeed, the form čoyin appears to most probably having been the Turkic originator of all the Yukaghir forms, hailing from *čo:, possibly *čo:n, as suggested by some forms. As is clear, there are some problems to overcome regarding the determination of chains of borrowings, as this word appears to have expectedly taken on the role of a Wanderwort. In any case, most likely, the final $-n$ was deleted as this is a genitive marker in Yukaghir. Further, I do note that the Russian word has also been borrowed into Ewenki in suffixed form. In other words, we can at least posit a borrowing chain for cast-iron going from Turkic [cast-iron; form with a plosive] > 


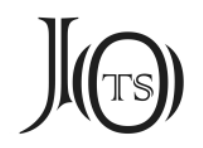

Russian [cast-iron] > Ewenki [cast-iron], and, separately from Turkic [cast-iron; form without a plosive] > Yukaghir [iron].

\begin{abstract}
New borrowing
Yakut emti 'обломить кусочек чего-либо = to break a piece of something', emtej'отламываться; отбиваться по краю; выщербляься = to break off; to fence off; to cave in', emterij 'откалываться = to chip away', emtegej 'с отбйтым краем; выщербленный; щербина = with a cleared edge; chipped; chink' (JRS 540), OR Ewen emteku 'проломанный, пробитый, прорубленный; пролом, пробоина, отверстие = broken, pierced, hacked; break, hole', emtekej 'проламывать, пробивать, прорубать = to breach, to pierce, to cut through' (Robbek \& Robbek 2005: 344), borrowed as: TY emt- in TY sal'gari:-emt-ekuu 'gaptoothed' (Kurilov 2201: 425; Nikolaeva 2006: 159)(< sal'gari: 'tooth', emt- 'broken off piece', ?ekuu 'hole' or < sal'gari: 'tooth', emtekuu 'broken').
\end{abstract}

The Yakut root is used in the expression tiis emtegeje 'щербина в зубе = chink in the tooth'. In Yukaghir, the meaning is exactly 'человек с выпавшим передним зубом [шербатый] = man with a fallen front tooth (gap-toothed)'. However, 'having a fallen tooth' is not the same as being 'gap-toothed', which usually just means 'a distance between two teeth'. The standard interpretation of the Yukaghir form would be 'tooth' + unknown + 'hole', where the part emtcould be borrowed, meaning something like 'hole; gap; chipped'. However, this segmental interpretation could be entirely wrong and the final part, -ekuu, may not be Yukaghir at all, but instead also belong to the borrowing. We would then interpret the compound meaning as: 'tooth' + unknown [emtekuu]. The unknown would then be close to Yakut emtegej 'chipped', and find an even closer match with the practically identical Ewen emteku 'broken'. The Yukaghir compound sal'gari-emtekuu would then have the literal meaning of 'broken tooth' or 'chipped tooth'. A 'broken tooth' may signify an altogether 'missing tooth' or a 'tooth with a chipped off piece', in other words 'gap-toothed'. Thus, the Ewen and Yakut forms are also connected, somehow through borrowing, and the donor language into this Yukaghir borrowing could be either language, most likely from Ewen in this case.

New borrowing

Proto-Turkic *oj- 'play; to play; to jump' (EDAL 1070) > Yakut oj- 'прыгать; скакать; перескакивать; перепрьггивать; подниматься, всходйть (о солнце) = to jump; to gallop; 


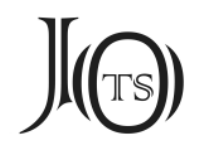

to jump over; to override; to rise (about the sun, etc.)' (JRS 267), borrowed as: KY ajdz-bude:npömerz- 'to somersault, lit. to jump and roll down from the top'; KD aide-bydien-ńuro- 'to somersault, lit. to jump and fall down from the top' (Nikolaeva 2006: 97).

All the words for a somersault, being a fairly complex maneuver as physical actions come, in Yukaghir are compounds and in at least two documented forms the first part is borrowed from Yakut oj- 'to jump' (>aj- in Yukaghir). The KY compound parts of the above are aj-dz- 'to jump (INTR)' ( $<P Y{ }^{*}-\delta e$, an intransitive verbal marker; Nikolaeva, I. 2006:79), bude: 'on the top of' and pömerə- 'to roll down', and in the KD form, instead nuro- 'to fall down' (cf. Finnish nurin 'in turned over position; inside out').

In KY, there is another parallel expression for somersault, but instead with all parts native Yukaghir, namely jo:-bude:n-pömere- 'to somersault', which literally means to roll down on the top of the head.

New borrowing

Written Mongol čoqu 'beetle, scarab, bug, tumblebug; black' (Lessing 1960: 199), etc., borrowed as: TY čuoqind'aа 'Черный жук = black beetle; a man in folklore, a man's name', čuoqind'aajetke 'черный жук огромного размера = black beetle of huge size', čuoqin ‘кличка собаки = a dog's nickname', čuoqind'aa ‘a man's name' (Kurilov 1990: 333; 2001: 572; Nikolaeva 2006: 141).

This constitutes another apparent Mongolic borrowing only into Tundra Yukaghir. Direct Mongolic borrowings into Yukaghir are exceedingly rare, if at all existing, and all such words have usually arrived into Yukaghir through Yakut, Ewen or Ewenki as intermediary transmitting language. The Mongolic meaning of beetle is kept intact in a phonologically close form in Yukaghir also meaning black beetle; the Mongol word has a homonym which means black, and so it is very fascinating that the dual meanings are actually found in Yukaghir black beetle. However, the Yukaghirs themselves likely do not regard the insect as being particularly black, so this correspondence could be merely circumstantial only, as in highest likelihood English just happens to call the insect a black beetle. We may assume that the word reached the Tundra Yukaghirs through wandering tales. This same word has also become a man's or dog's nickname (although in this case possibly only used with black dogs if the word retains any of its 


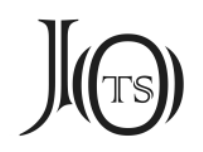

original Mongolic connotation) - perhaps hinting at the very origin of the word through tales - and in all cases the root bears an affective nominal derivational suffix commonly found exactly with names - both with folklore and common Yukaghir names - namely -aa (Piispanen 2016: 215; indeed, the TY man's name of čuogind'aa is given as non-etymologized therein on page 213). The word is noticeably formed in paradigmatic pattern with other names bearing the same suffix, cf. TY qarqind'aa 'a female's name, lit. woman of the steep bank'. The origin of the $-n-\sim-n-$ in the Yukaghir forms is not clear, but could constitute an attributive marker.

The Mongolic form is not widely attested and found only in Written Mongol, Khalkha and Buryat; B. Brosig suggests that these forms are Turkic borrowings, and that no Proto-Mongolic form (as given in EDAL 412) should be reconstructed. It has been compared (EDAL 412) to Proto-Tungusic *čaKu- ( $\sim$ š-) 'a kind of midge (мошка-мокрец)' (TMS 2 379), attested only in Ewenki, Negidal, Ulcha and Nanai, and to Proto-Turkic *cekü-rtke 'саранча, кузнечик = locust, grasshopper', attested in numerous languages (VEWT 103; EDT 416-417; Leksika 187). I note that while all of these words describe insects, there are fairly large differences between a beetle (Mongolic) and a midge (Tungusic), and the comparison is not entirely satisfactory despite the close phonology, although a long period of time could admittedly have given arise to a semantic change in Tungusic. The comparison of a beetle (Mongolic) and a locust (Turkic) is more acceptable. The fairly low level of attestation of these roots in both the Tungusic and Mongolic branches may suggest that the root was borrowed into individual languages or close clusters of languages from Turkic sources, which also gave rise to a semantic shifts at the point of borrowing (and indeed a Proto-Mongolic root is missing from those safely reconstructed in Nugteren 2011).

My colleague M. CRNOBRNJA pointed out the possibility of sound symbolism for this root, cf. Rus. жук 'beetle' \& жужжкать 'to buzz, to hum', the insect name possibly being derived from the verb. However, it seems less likely that such parallel developments would also have occurred in Mongolic as well as in Yukaghir. Nevertheless, the possibility should be noted for future reference. 


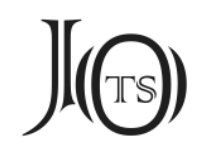

New borrowing

?Proto-Tungusic *lapta 'flat, level; fish fins' (TMS 1494,584 ; EDAL 867) > Ewenki lopčoj 'рыбий хвост = fish tail' (Vasilevič 1958: 238; lāpčā 'fish fins' in the EDAL), borrowed as: KY lopčə 'a man in folklore'; KJ lončuo (rect. lopčuo) (Nikolaeva 2006: 249).

Folklore in Yukaghir is naturally composed not only of native tales (which can be enjoyed for example in: Bogoras 2009, currently for sale), but also of the tales of other surrounding or intermixing populations, historical or current. The Kolyma Yukaghir tale discussed here likely had a protagonist with the name of 'fish tail', which well follows the style of Yukaghir tale naming conventions. The word must have originated in Ewenki, and been adopted almost verbatim but adjusted to Yukaghir prosody, through such a "borrowed" tale. The Ewenki word would seem to be Tungusic, having arisen from Proto-Tungusic *lapta 'flat, level; fish fins' (TMS 1494, 584; EDAL 867) (also > Ewenki napta- lapta- 'flat, level'), which curiously seems to have parallels with Proto-Uralic *lappa lapta 'flat' (UEW 237, 238). The phonological overlap is excellent, but the semantics cannot be verified without knowing exactly which Yukaghir story we are discussing here; the protagonist was likely a fisher, and the story likely involved fishing, or possibly sea spirits or the like, which is common to the stories.

New borrowing

Yakut bočuguras 'рябчик = hazel grouse (Tetrastes bonasia)' (JRS 77), bočurgas 'Haselhuhn = hazel grouse' (Middendorff 1851: 135; “Old Yakut”), borrowed as: KY posturge: posturgie 'глухарь (самка) = grey female of a capercaillie (Tetrao urogallos)' (< *botsurgas) (Nikolaeva-Shalugin 2002: 62; Nikolaeva 2006: 363); SD bostirgo 'тетерев = black grouse (Lyrurus tetrix)' (Spiridonov 2003: 10).

This constitutes another faunistic borrowing from Yakut into Yukaghir dialects only. The Yakut word for 'hazel grouse' is etymologically derived from the verb bočuguraa- 'щебетать, Свиристеть = to chirp, to make whistling sounds with hissing and creaking', which describes the animal's sounds well, and which also gives us the direction of borrowing: Yakut > Yukaghir. As Nikolaeva noted, the Yukaghir synharmonism is irregular, and the reason for this is likely borrowing. The semantics makes perfect sense (including narrowing in meaning with the borrowing into KY, but retention of meaning into SD), and the phonology, 


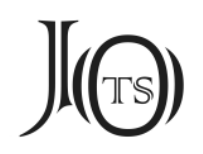

using the older Yakut form, is straight-forward, with de-affrication $\left(* \check{c}>*_{t s}\right)$, i.e. we may posit "Old Yakut" bočurgas > botsurgas > posturge:. The vocalism of 'grouse' is a perfect match between the Old Yakut and the KY form, but the SD form, as usual, exhibits irregularities. I note that the Yakut word itself probably originates etymologically from the verb bočuguraa- 'щебетать, свиристеть = to chirp' (JRS 77) (unless the verb was created exactly to describe the bird's sound) and this gives us the direction of borrowing of Yakut > Yukaghir.

New borrowing

Yakut seпije ‘подбородок = chin' (JRS 368), borrowed as: MU tschimíe, schimíe, tschymíe 'lip; chin; cheek' (Nikolaeva 2006: 132) (<* simije).

A rare documented old Yukaghir MU word for 'chin' is found probably borrowed from Yakut. This record, collected at Ust'-Janskoe at the mouth of the Jana, belongs to the next oldest Yukaghir materials ever as recorded by Lindenau and Mueller in 1741 . These old records rarely display an exact phonological correspondence neither with the modern Yukaghir forms nor with the forms found in other languages if they were borrowed terms. Actually, many SD, MU and MK forms are phonologically aberrant and therefore often believed to be erroneous records. While this is naturally not always so, assuming aberration is often a working hypothesis for finding other possible Yukaghir cognates or exterior sources in the case of borrowings. The language recorded as MU seems to have been a mixture of Yukaghir dialects with an Ewen component, so it is perhaps a bit surprising to find an isolated Yakut borrowing there. On the other hand, words such as MU totex 'thou' (cmp. KY tot 'thou') - with what appears to be traces of the in-Yakut typical change *-eq >-ex - may suggest, in particular given the very nature of this word, a fairly strong simultaneous Yakut element there as well. I suggest that we may assume that MU was in close contact with both Yakut and Ewen.

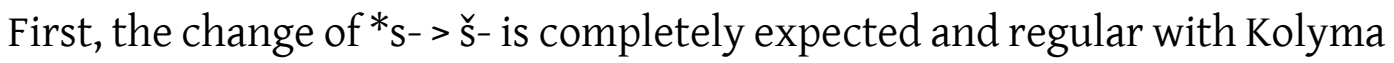
Yukaghir (contrary to Tundra Yukaghir) and seems to have occurred here as well, cf. KY šojl'bul 'mouse' MU dschalbýl 'mouse' (Nikolaeva 2006: 410). The rendering of the latter as an affricate may possibly be attributed to differences in 


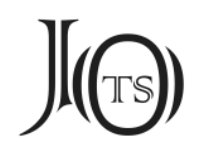

pronunciation between female and male informants. Second, the words end, $i(j) e$, is matching perfectly between the Yakut and MU words and likely carried over with the borrowing (even though there exists a hitherto non-discussed nominal derivational suffix *-jə in Yukaghir). Third, the first vowel may have changed from $-e$ - to $-i$ - due to regressive vowel assimilation - an harmonizing, "evening-out" effect affecting vowels in this Yukaghir word. This borrowing suggestion does not, however, come without phonological problems as the change of $-\eta->-m$ - has to be assumed (unless the record is faulty), but this too has at least a few rare parallels in Yukaghir lexicon. Despite this phonological problem it would be greatly surprising if this would not be a Yakut borrowing into MU only as outlined here. We may thus assume Yakut senije 'chin', borrowed into Old Yukaghir as *simije 'chin'.

Another comparison of interest may be to Proto-Nivkh *cin'y 'shin' > Amur Nivkh c'in'x 'shin'; Northern Sakhalin Nivkh c'in'x 'shin'; Southern Sakhalin Nivkh cin'x 'shin' (Fortescue, M. 2016:33), which - given that the Yakut for appears to be non-etymologized - may actually be, I boldly suggest, the source language in the form of the now extinct hypothetical Northern Nivkh for a borrowing into Yakut (and subsequently into Yukaghir).

New borrowing

Proto-Northern Tungusic *koyno- 'to become black' > Ewenki koynoriin 'black', koynomuk 'blackness, darkness' and numerous derivatives (\& Ewen qoonal- 'to appear to be black', qoonańa 'black, dark'; Solon xonnorin 'black'; Neghidal konniyin 'black') (TMS 1413 ), borrowed as: B konondschi 'stone used as black paint' ( * *kono-ńča; Nikolaeva 2006: 221 hesitantly gave this as *könöńči).

This isolated Yukaghir word is from the field records of Joseph Billings during his North-Eastern Expedition of 1785-1793) is another northern Tungusic borrowing, and then more specifically from Ewenki, as evident from the high round vowels, -o(y)no-. The records reflect the Kolyma Yukaghir variant of the Kolym-cy tribe at the mouth of the river Nelemnaja in the settlement of Nungadon-ayil' during the $18^{\text {th }}$ century. Given the Tungusic correspondence, the B form can safely be segmented as *kono-ńča, reconstructed here, containing a borrowed bare verbal root with high back vowels and then suffixed with a common 


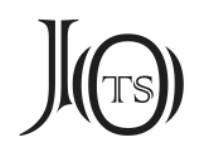

nominal derivational suffix (Nikolaeva 2006: 80). The meaning is thus rendered 'thing through which to become black' or, simpler, 'black coloring thing', which is exactly what a 'stone used as black paint' is.

These Tungusic forms have actually been suggested old Eskimo borrowings only into Northern Tungusic (Vovin 2015: 93), cf. Central Alaskan Yup'ik əRnəX$\operatorname{tuR}(a q)$ 'blue, grey fox'; Seward Peninsula Inuit qiRniq- 'to be dark colored, black'; North Alaskan Inuit qiRnyiq- 'to be black, dark'; Western Canadian Inuit qinRiq'to be black, dark'; Eastern Canadian Inuit qiRnitaq 'something black'; Greenlandic Inuit qiRniR- 'be black' < Proto-Eskimo *qiRnaR- 'to be black or dark' (CED 1994: 308). I fully agree with this take, as there are also numerous ancient Yup'ik Eskimo borrowings to be found in the Yukaghir languages and dialects (forthcoming).

New borrowing

Proto-Tungusic *pige * piage 'kite' (TMS 2 322-323) > Erbogočjohskij Ewenki hizen 'kite' and Podkamennyi Ewenki hizen 'goshawk' (Vasilevič 1958: 477), as well as dial. Ewenki sigečēn 'коршун; сова = kite; owl' (Vasilevič 1958: 351), borrowed as: KY śegen 'kite' (NikolaevaShalugin 2002: 66), čegen 'kite and other predatory birds' (Nikolaeva 2006: 238).

This borrowing suggestion comes with phonological problems until one looks at dialectal Ewenki forms, and the semantic overlap is perfect with the meaning of 'kite'. The borrowing is found attested only in modern Kolyma Yukaghir, and can be assumed to be very recent. It would therefore seem as if the borrowing was made from the dialectal Ewenki form, sigečen, which retained the word-initial s-. The palatal Yukaghir ś-, then, must have arisen spontaneously due to the following high vowel $-i-$. This Yukaghir form was then furthermore changed into $\check{c}_{\text {- }}$ in some local dialectal form. ${ }^{3}$ This Tungusic root is well-attested and found represented in Ewen, Ewenki, Negidal, Ulcha, Orok, Oroch, Nanai and Solon, and the direction of the suggested borrowing would therefore automatically be from Tungusic to Yukaghir.

3 Unless, of course, the existence of two different recorded KY forms may be possibly be ascribed to the phonological differences between male and female pronunciation. Such differences are indeed known to exist for sibilants/affricates. 


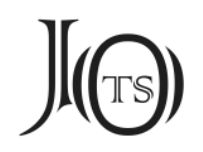

There is also a somewhat similar KY če:n 'eagle'; KJ čien; SD sejien; MC čeinga (reconstructed as PY *sejey mostly based on the SD form; Nikolaeva 2006: 128), but that may be unrelated to the matter at hand. My colleague M. Crnobrnja brought up Proto-Nivkh *čhamy 'eagle' (suggested by A. Vovin instead as *čamy 'eagle' as given by FORTESCUE) for a comparison, and which I know exists in Mudrak's inofficial comparative database as well; the comparison with Yukaghir was then made elsewhere (Nikolaeav 2015: 54). This comparison, however, does not work because a structure such as *samVy would retain the root-initial sibilant in Yukaghir (Piispanen 2015: 252), and connecting it to Yukaghir *sejey is therefore impossible. Connecting the Yukaghir words to the Tungusic forms is therefore the most sensible solution.

\section{Other tentative suggestions}

In this section, I list ten additional suggestions between some lexical correspondences that may constitute borrowings, although the similarities could instead represent mere coincidental similarities. All of these suggestions have either gross phonological or semantic problems, and are to be considered tentative only.

Tentative borrowing

?Ewen mēnkeme 'просто так; попусту; бесцельно = just; in vain; aimlessly'; mēnitken хučiri 'man thinking only of himself, egoist' (<mēni 'self) (Robbek \& Robbek 2005: 179), borrowed as: TY megeče ‘негодник = wretch, man good for nothing' (?< *menkə-če:) (Kurilov 2001: 274; Nikolaeva 2006: 262). Also: TY meńi:ke:n ‘a man' (Nikolaeva 2006: 265).

A rare word found only in Tundra Yukaghir meaning 'man good for nothing' appears to be an Ewen borrowing. Ewen has a number of phonologically very similar words with semantically connected meanings: 'in vain', 'egoist', 'self. The same root as was supposedly borrowed is also used in an Ewen expression meaning 'egoist', which corresponds well to Yukaghir 'man good for nothing'. Phonologically, it appears as if the Ewen word menkeme was borrowed as Yukaghir *meykə- (*-nk- because otherwise TY would regularly evidence *-nk- > TY -ng-), to which the TY nominal derivational suffix -če: (Nikolaeva 2006: 79) was attached. This form then predictably became TY megeče, and I assume that it also 


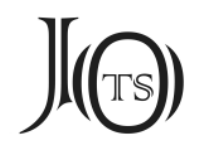

existed at least in TK and TD, but was never recorded as such. The addition of the Yukaghir suffix suggests the direction of borrowing from Ewen into Yukaghir, with the etymology of the Ewen otherwise not being clear. This suggestion is difficult to verify through various means, but the Ewen and Yukaghir forms appears a fairly close match both phonologically and semantically suggesting that this is indeed a borrowing. While the borrowing of TY megeče may be hypothetical (<*menkə-če: < mēnkeme), the borrowing of TY meni:ke:n 'a man (likely in a story)', hitherto also non-etymologized, is definite (it is from Ewen mēnitken 'egoist').

\section{Tentative borrowing}

Written Mongolian čoqu- 'to agree, to affirm, to confirm; to make a decision; to make a resolution' (Lessing 1960: 199), etc., borrowed as: TY čokuoju 'совершенно = perfectly, absolutely’ (Kurilov 1990: 326; 2001: 558; Nikolaeva 2006: 137).

This could constitute another Mongolic borrowing only into modern Tundra Yukaghir. In Mongolic, this root is attested also in Khalkha, Buryat and Ordos. If correct, how did this borrowing find itself into Yukaghir? And through which intermediary proxy language? B. Brosig denies any possibility of reconstructing a Proto-Mongolic or even a Proto-Central-Mongolic root for this (contrary to EDAL 441, and it is indeed missing in Nugteren 2011), and suggests that the Mongolic root is somehow related to 'putting seals and stamps', the impact of which on this borrowing suggestion is unclear.

Tentative borrowing

Proto-Tungusic *muru- 'обходить вокруг' (TMS 1 559) > Ewenki murumi- ‘повернуться вполоборота (о человеке) = to turn around (about a man)', murukte-mi 'обойти вокруг (чего-либо); разломить, разрезать; вырезать круг = to walk around (something); to break, to cut; to cut circle’, murūkē-mī murēkē-mī 'бродить вокруг; колесить, обходить, объезжать, окружать = to wander around' (Vasilevič 1958: 265-266); Ewen merъktej 'возвратиться, вернуться домой = to return, to come back home', merøkedek ‘возвращение = homecoming' (Robbek \& Robbek 2005: 181) (TMS 1559-560; EDAL 955), borrowed as: TD mered'eń- 'to visit'; KY me:rz- 'to drive off, to keep off', KD m'ere-, mere(Nikolaeva 2006: 266); KJ mureino- 'to wander, to migrate', merieš- 'davontragen = to carry off , merūci- 'durchgehen, passieren, vergehen, vorübergehen = to pass through, to happen, to pass away, to pass over'; TJ meru- merū- 'hingehen (INTR) = to go forth' (Angere 1957: 154-155). Also: TY meruu 'a form of ritual fire' (Kurilov 2001: 277). 


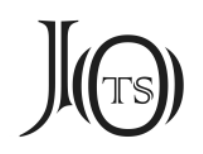

Another problematic suggestion. The phonological correspondences are probably acceptable, but the semantics do not overlap well. In Ewenki the meaning is 'to walk around > to return', but in Yukaghir it is merely 'to walk away, to pass through'. Certainly, Yukaghir 'to visit' implies a later 'return' as in Ewenki, but this is not entirely convincing.

Tentative borrowing

?Rus. paj 'часть = share, piece', borrowed as: Yakut paj 'пай = share', pajdaax 'имеющий пай = having a share', pajdan- 'иметь, приобретать пай = to have or acquire a share' (JRS 292), borrowed as: МС baj 'вкусъ = taste', bajut 'кормить = to feed' $(<$ *paj $)($ Wrangel 1841: 117,118; Nikolaeva 2006: 341).

Two rare documented words in MC meaning with 'taste' and 'to feed' could be Yakut borrowings, which originate in Russian from an original meaning of 'share'. Despite the given meaning of 'taste', as in the sense of taste, the semantic connection between the two respective MC words meaning 'share' and 'to feed' together do suggest that MC baj should really describe a 'morsel', 'a piece of food'. Thus, receiving a 'piece of food', or rather, a 'share (of food)', equals to receiving a 'taste (of a piece of food)', and the verbal form is consequently 'to feed (a piece of food)'; this has parallels in other languages, including the Uralic ones. The phonologic overlap is perfect, and given the semantic connection suggested above, if the correction and argumentation is accepted, this is another prospective borrowing. This suggestion should be compared to another known, relevant borrowing: Rus. paj 'часть = share, piece', borrowed as Kolyma Yukaghir pajl 'part, share'; Tundra Yukaghir pai, dialectal. painol 'part, share' (Nikolaeva, I. 2006:340; Anikin, A. Ye. (2003:429), and could, due to the extensive geographical spread be a very early Russian borrowing into all of these Yukaghir forms: KY, $\mathrm{KK}, \mathrm{KJ}, \mathrm{KD} ; \mathrm{TD}$, as well as the MC presented here.

Tentative borrowing

?Yakut xoluj- 'полагать, считать; сравнивать, уподоблЯть = to believe, to consider; to compare, to liken' (JRS 495), borrowed as: KY qolluj- 'to envy (INTR)', KD xollui-, TY qollej-; RS konloi, KY qollujo:rz- 'завидовать = to envy very much (TR)', qolluji:l 'envy' (NikolaevaShalugin 2003: 76), ТY qollej- 'завидовать = to envy', qollii- 'to cause to envy', qollijuori- 


\section{J(৫)}

'смотреть на что-л. с завистью = to look at something with envy'; qollerii 'a dog's name' (Kurilov 2001: 519; Nikolaeva 2006: 384).

The phonology of this tentative Yakut verb borrowing into Yukaghir is virtually flawless (< Pre-Yakut *qoluj-), however, the semantics are trickier to explain and justify, and the similarities may thus be accidental only. Psychologically speaking, envy is an emotion directed at others, wanting their qualities, success, or possession. As such it involves comparison and contrast. Contrasting yourself with an idealized image of another person magnifies shame which can threaten your self-stability - any threat to your self-image will activate shame, and when found lacking through contrast the shame is experienced as envy or jealousy of another. Could therefore the Yakut verb meaning simply to compare have become semantically narrowed down to envy in Yukaghir?

Additionally, to complicate the analysis further, there is another comparison to be made, namely to: Proto-Central-Mongolic *golu- 'to be unhappy with smth., to consider smth. bad' > Written Mongolian yolu- golu- 'to abhor, to loathe, to condemn; to be fastidious; to refuse, to despise (as being below one's dignity); to reject' (Lessing 1960: 359); Written Mongolian qolu- (Lewicki 1949: 36); Khalkha golo-; Buryat qolo-; Kalmuck yol- (Ramstedt 1935: 150). ${ }^{4}$ The Mongolic form has excellent overlap both phonologically and semantically with the Yukaghir forms, and actually also with the Yakut form, and this could be another Mongolic borrowing into Yakut, with the semantics of the Yakut form having changed after the borrowing but before the subsequent borrowing into Yukaghir. As such, we could assume an early borrowing sequence of Mongolic > Pre-Yakut > Yukaghir for this root, if the suggestion is correct.

Tentative borrowing

?Proto-Mongolic *aju- *ayu- 'to fear' (EDAL 496-497; Nugteren 2011: 275-276) > Written Mongolian aju- aji- 'to fear, to become frightened or afraid', ajul 'fear, horror, fright; danger, risk; catastrophe, disaster, peril, jeopardy, menace; misfortune', ajulga- 'to frighten, to intimidate, to terrorize, to threaten, to menace, to bluff, ajulta 'fear, danger, risk', ajumtagai 'fearful, timid; cautious; cowardly shy', etc. (Lessing 1960: 24-25); Middle Mongolian aju-, àj-

4 My colleague B. BRosig suggests - contrary to EDAL 555 - that only a Proto-Central-Mongolic root can be reconstructed for this root at best. 


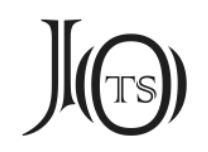

, aj- 'to be afraid', ajl 'fear; causative: ajula-', etc., borrowed as: TY el'uguon-l'ie (< *ejl'a) 'выражает угрозу: погоди же; смотри же; INTJ: threatening'; TD eilegoneili; KD eil'ere 'to be afraid of (TR)'; eil'ere(bo)- 'timid, shy', ejlereboi- 'timid; fearful; weak-hearted' (Angere 1957: 52; Kurilov 2001: 597); ТY el'uguon(-el'i) 'выражает пожелание, просьбу повременить с чём-либо: погоди-ка, постой-ка; INTJ: wait!' (Kurilov 2001: 597; Nikolaeva 2006: 153).

An interjection found in both KY and TY signifying fear, of which there also exists verbal forms, appear to be of Mongolic origin, but it could alternatively be merely onomatopoetic and be wholly unrelated. The secondary semantic development in Mongolic is paralleled in Yukaghir. If of Mongolic origin, it appears to have received the common, epethetic $-l-$, which regularly appears in Yukaghir after any intervocalic semivowel -j- (Maslova 2003: 56), i.e. *aju > *ajlu > *ejl'u(through palatalization), and also the prosodically valid form ejl'o-.

The Mongolic root is extensively attested throughout the Mongolic languages (EDAL 496-497; Nugteren 2011: 275-276; Sanzheev et al. 2015a: 61-62). Nugteren mentions the comparison to archaic Old Turkic ayïn- 'to fear' and appears to agree with the referenced Clauson that it is 'probably fortuitous'; however, there is no real reason to assume that the Turkic and Mongolic forms are merely accidentally similar - with very numerous borrowings known between these two - but rather this root is probably also connected between the two at the very least through borrowing. M. CRNOBRNJA noted that the alternation-gar : -ai-for the adjective describing a physical feature and a verb that relates to it is very common in Khalkha and Buryat, which may also be applicable here. Furthermore, I note that there is a deverbal nominalizing suffix -gar in Dolgan (and likely also in Yakut) which creates adjectives (Stachowski 1997: 42-43). Stachowski believed that the suffix was borrowed from Mongolic into Yakut/Dolgan, but I find such a thesis non-agreeable. What all this means, however, is that there may have been an unattested, intermediate Yakut form, borrowed from Mongolic, and acting as a donor root into Yukaghir in ancient times. After all, most, if not all, Mongolic borrowings into Yukaghir likely reached there only through Tungusic or Yakut as intermediary donor languages. 


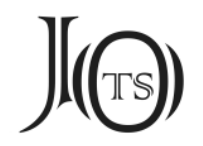

Tentative borrowing

?Yakut nanayar 'широкогрудый (о толстом , плотном человеке) = broad-chested (about a thick, dense man)'; nanaj- 'выставлять широкую грудь = to exhibit a broad chest'; työskyn nanatan qaатр 'ходйть, выставив широкую грудь = to walk putting out a broad chest' (JRS 252), borrowed as: (PY *na:n- >) KY na:n 'upper part of the chest'; TY naan 'upper front part of a breast cloth'; TK naan; TD nan-amun 'collar-bow' (sic? Should probably be 'collar-bone', i.e. < amun 'bone'); SU ńanic; TY naan-čiid-ojoj 'внутренний нагрудный карман дохи = inner breast pocket (of a doha), lit. breast cloth people pocket'; TK naan-čiid-ojoj; TY naandukun 'специально выделанный лоскут шкуры, носимый на груди для предохранения ее от холода = piece of skin which is worn on the breast for protection from cold, lit. breast cloth thing'; TK naan-dukun; KY ńa:d-albə-jurgu:, ńa:n-jurgu: 'pit above the collar-bone, lit. hole in the upper part of the chest'; KD nay-irgu, na-yirgu 'pit between the throat and the chest'; KY ńa:ńz-peššej- 'to have a rest, lit. to throw the upper part of the chest'; TD ńandigeye 'strap made of walrus leather' (Nikolaeva 2006: 287-288). Also: TY паan 'нагрудная часть женских меховых трусов; нагрудник (выделанная шкура, носимая на груди); грудная часть верхней одежды; пазуха = breastpiece of female fur briefs; bib (a dressed skirt worn on the chest); breast part of outer clothing; bosom'; naanńe- ‘иметь нагрудную часть (о меховых трусах) = to have a chest piece (about fur briefs)' (Kurilov 2001: 278-279).

As Nikolaeva notes the KY first consonant was irregularly palatalized before the long vowel; since most dialects have a non-palatalized first consonant the reconstructed form should also be non-palatalized. This reconstructed Yukaghir form is an excellent phonological fit with the Yakut words, and a connection, through lexical borrowing, is possible. However, while both languages (Yukaghir and Yakut) seemingly exhibit the same phonological root - albeit with no suffixes "carried over" - none of the forms are semantically exactly the same between the languages, meaning that the similarities could be coincidental only.

However, the semantics, of all things possible in the world, all do pertain to the upper chest in different forms; this is a very perplexing case. Further, if a borrowing, the direction of such a tentative borrowing is not clear either. Considering the extensive spread throughout many Yukaghir dialects and languages, it is possible that this could constitute a rare Yukaghir borrowing into Yakut, instead of the opposite direction as usually assumed, particularly since the Yakut words, to the best of my knowledge, have no other exterior comparanda. 


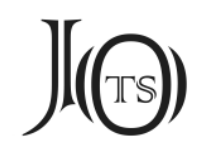

Tentative borrowing

?Yakut ahut 'бродить = to roam' (? * *ayut) (JRS 50), borrowed as: SD agurtejen 'бродить = to roam' (?<agut-teje-n) (Spiridonov 2003: 7).

An isolated Yukaghir form noted by Spiridonov meaning 'to roam' could be a Yakut borrowing from a verb meaning the same. In Old Yukaghir, in particular, I note that -teje- is a common ending for verbs of movement, and the final $-n$ is also part of a verbal stem. If this assumption is correct, then the borrowed SD verb could be segmented as *agu-t-teje-n $>\mathrm{SD}$ agurtejen. The change of $t>r$ with the borrowing could have arisen spontaneously, partly driven by the prosodic need to avoid geminates in this position. The direction of borrowing is, despite the etymology of the Yakut form not being clear, from Yakut into dialectal Yukaghir as it seems exceedingly unlikely that standard Yakut could have borrowed this word from a minor Yukaghir dialect.

Tentative borrowing

?Proto-Turkic *kömek 'help' (EDAL 759; ЭСТЯ 5 98-99) > Yakut kömö ‘помощь, содействие; пособие = help, assistance; benefit', kömölöö- 'нападать вместе, действовать сообща = to attack together, to act together', kömölööx 'получающий помощь; помогающий, полезный = receiving help; helping, useful', kömölös- 'помогать; содейстq вовать, оказывать помощь = to help; to contribute, to assist', kömöltö 'помощь, поддержка, содействие = help, support, assistance', etc. (JRS 177), borrowed as: KY qame:- qame:d'ə- ‘to help', qamulo:- 'to work for', qamlo:- 'to serve', qamlo:d'a 'servant'; TY qamul(') qamdiil qamriil 'наемный работник = employee, servant', qamda- qamlaa- 'to serve', qaml'aa- 'to serve', qomul' 'task', qomure- ‘to set a task' (Kurilov 2001: 506; Nikolaeva 2006: 376).

Nikolaeva's dictionary suggested a connection for the Yukaghir words to Proto-Tungusic *papa- * paba- 'to work' (TMS 2 307), but I suggest that due to insurmountably large differences in both phonology and semantics this root cannot really have anything do with it. I will therefore suggest another possible Yakut borrowing etymology.

The suggestion outlined above represents another ancient borrowing from Pre-Yakut (also called old Yakut in other sources) found borrowed both into KY and TY. The phonological correspondence may not be obvious, even though the semantics are identical. The donor was Old Yakut *kömö 'help'. It occurred early 


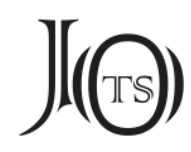

because of extensive adjustment to Yukaghir prosody and phonology, because secondary semantic forms have had time to develop and because it is also very well-attested and geographically spread out. Phonologically, the borrowing is not fully regular. The borrowed root in Yukaghir appears to have been *kom'help', which became *qom- and was thereafter uvularized driven by the q-. (i.e. *kom- > *qom- > *qam-); uvularization occurs irregularly and unpredictably in Yukaghir, and there are scattered examples. Seemingly, the intermediate nonuvularized form, *qom-, is still found with two words in TY: qomul' and qomure-. However, *qom- could, alternatively, have redeveloped from *qam- (there are a few such examples as well in Yukaghir lexicon). The uvularization hypothesis could hold true if *kömö was the original form.

In Nikolaeva's dictionary, the entry for the PY root *qam- appears contaminated with other Tundra Yukaghir words having a connotation to 'feeling shy or ashamed'; from a semantic point of view these must be considered unrelated to the root handled here, and could represent separate borrowings (as the words are not well-attested).

Tentative borrowing

\begin{abstract}
?Yakut alaj- ‘иметь добродушно-глуповатый вид, глядеть непонимающе, полуоткрыв рот = to have a good-naturedly silly look, to look blankly, half-open mouth' (JRS 37), borrowed as: MO (ildil-)-alelbu 'глупо = stupid (person);' (?< *ala(j)-l-pə) (Wrangel 1841: 119; Nikolaeva 2006: 101).
\end{abstract}

This may constitute a rare Yakut borrowing only into the Omok language. The MO word may be suffixed with the inchoative verbal suffix *-lpa (Nikolaeva, I. 2006:81), with the rendered meaning of 'to become gaping, to go gaping', i.e. 'stupid'. The first part, ildil-, simply means 'person', so the given Yukaghir meaning is stupid person, or if this suggestion is correct, literally, 'person going around with a half-open, gaping mouth'. While the etymology of the Yakut form is not clear, the direction of borrowing is most likely Yakut > Yukaghir, as it so often is.

The Yakut word is seemingly, as suggested by A. Savelyev, related to the family of Turkic *al-initial words for 'dumb, foolish', 'crazy, mad', etc. (EDAL 286287 , given there with no less than nineteen basic meanings). Cognates of these 


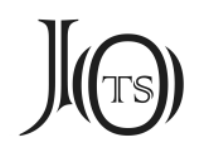

roots, which could benefit from some cleanup work and separation by morphological analyses (are given elsewhere: VEWT 16-17; TMN 2 116; EDT 129, 138, 149; ЭСТЯ 1 132, 145-146). A related word may be Yakut alyas 'error', and it seems therefore likely that one similar derivative, perhaps non-attested, was borrowed into the Omok language.

\section{Structured semantic fields}

Dividing the found borrowings into various cultural and technological spheres of semantics (as per Rédei 1999), produces the following groups:

a. body parts of humans and animals: chin (Yakut), fish tail (Ewenki), upper part of the chest (tentative, Yakut)

b. animal kingdom (i.e. fauna): bean goose (Mongolic via Yakut), grouse (Yakut), black-beetle (Mongolic), kite (Ewenki)

e. types of work and tools: ski (Ewenki), stone used as black paint (Ewenki)

f. trade: iron (Turkic), material losses (Yakut)

i. social life and kinship terms: elder sister (Ewen), role (Russian via Yakut), wretch (tentative, Ewen)

m. elementary phenomena, actions and perceptions: to jump (Yakut), to order (Yakut), to envy (tentative, Yakut), to be afraid (tentative, Mongolic), to roam (tentative, Yakut), to serve (tentative, Yakut) to wander visit (tentative, Ewenki), taste (tentative, Russian via Yakut)

n. other: good (Yakut), broken (Ewen), absolutely (tentative, Mongolic), stupid (tentative, Yakut)

The following categories had no representatives among the borrowings: $\mathrm{c}$. plant kingdom (i.e. flora), d. nature, natural phenomena and natural places, g. habitation, h. clothing, j. tribal or population names, k. health, illness and death, 1. religion. As has also been the case with the previously suggested borrowings of earlier parts of this paper series, the borrowings have occurred in practically all semantic fields, which speaks for very intense language contacts. For example, everything of the Russian civilization was generally perceived to be of superior 


\title{
$J(\Theta)$
}

quality (which Jochelson pointed out numerous times in his summarized field studies), which is why words for numerous trade items, but also many other Russian terms were generously borrowed into Yukaghir. The borrowing of very basic terms, then, already available in Yukaghir - creating a synonym or even exchanging the native word entirely - speaks for a situation where many speakers had become multilingual, with common code-switching in speech, as well as language changing perhaps into locally perceived more prestigious languages. In fact, many Russian trade items were borrowed by way of the Yakut language, which has been demonstrated elsewhere (Piispanen 2019c) and which again highlights the very extensive language contacts. Many youngsters may have become increasingly Russianized and married with partners from non-Yukaghir "tribes". Eventually many Yukaghir groups - which in historical times were very numerous - were broken up, and assimilated, and the native Yukaghir language was lost and exchanged with others despite in many cases retaining the Yukaghir ethnicity; the result is, sadly, the very low number of current speakers, all of which appear to become increasingly elderly. While Yukaghir is considered critically endangered, there appears to be some small revival movements going on, as well as, as to the best of my understanding, Yukaghir language courses given somewhere in St. Petersburg, Russia. It is my hope that this paper series focusing on the Yukaghir languages and dialects has shed some insights into the general historical language contact situation of the far northeastern Siberia, and that interest into the fascinating and culturally and ethnolinguistically important Yukaghir languages is renewed!

\author{
Abbreviations \\ $\mathrm{B}=$ Materials of Billings 1787. \\ $\mathrm{BO}=$ Materials of Boensing 1781 . \\ CED = Fortescue-Kaplan 2001. \\ EDAL = Starostin et. al. 2003. \\ EDT = Clauson 1972 .
}

Egerov $=$ Yegorov 1964 . 


\section{J(৫)}

ESTY $=$ Sevortjan 1974-2000.

Fedotov = Fedotov 1996

JLTT = Martin 1987.

JRS = Slepcov 1972

$\mathrm{KD}=$ Kolyma Yukaghir from Jochelson's manuscript dictionary.

KJ = Kolyma Yukaghir materials of Jochelson 1898 and 1900.

KK = Kolyma Yukaghir materials of Krejnovič 1982.

$\mathrm{KL}=$ Materials of Klitschka 1781.

KW = Ramstedt 1935.

KY = Modern Kolyma Yukaghir.

Leksika = Tenišev 1997.

Leksika = Tenišev 1997.

$\mathrm{M}=$ Materials by Maydell presented by Schiefner 1871a and 1871b.

MC = Chuvan materials of Matjuškin in Wrangel 1841.

ME $=$ Materials of Merk 1787.

MGCD = (1990) Menggu yuzu yuyen cidien, Qinghai.

MK = Kolyma Yukaghir materials of Mueller and Lindenau in 1741.

MNyTESz = A magyar nyelv történeti-etimológiai szótára I-III, Budapest, 19671976.

MO = Omok materials of Matjuškin in Wrangel 1841.

MU = Ust'-Janskoe materials of Mueller/Lindenau 1741.

RS = Materials of Rajskij and Stubendorf presented by Schiefner 1871a.

SD = Kolyma Yukaghir materials of Spiridonov 2003.

$\mathrm{SU}=$ Materials by Suvorov presented by Schiefner 1871a.

$\mathrm{TD}=$ Tundra Yukaghir materials of Jochelson 1926.

TK = Tundra Yukaghir materials of Krejnovič 1958 and Krejnovič 1982.

TY = Modern Tundra Yukaghir. 


\section{J(৫)}

$\mathrm{W}=$ Early materials of Witsen in 1692. All the older materials are fully described and referenced in Nikolaeva 2006.

\section{References}

ANGERE, J. (1957). Jukagirisch-Deutsches Wörterbuch, Wiesbaden: Otto Harrassowitz.

ANIKIN, A. E. (2003). Etimologičeskij slovar russkix dialektov sibiri, zaimstvovaniya iz ural'skix, altajskix i paleoaziatskix jazykov, Moscow-Novosibirsk: Nauka.

ATlasova, E. S. (2007). Slovar' jukagirsko-russkij i russko-jukagirskij (tundrenyj dialekti) - okolo 3500 slov, St. Peterburg: Filial izdatel'stva <prosveshchenije>.

BATTAL, A. (1934). İbnü-Mühenna Lûgati, Istanbul.

BEREZKIN, Y. (2010). “Tricksters trot to America - areal distribution of folklore motifs", Folklore, 46: 125-142.

Bogoras, W. (2009) Tales of Yukaghir, International Polar Institute Press. [reprint of the 1918 materials]

Clauson, Sir G. (1972). Etymological dictionary of Prethirteenth Century Turkish, Oxford: Clarendon.

DoERfer, G. (1985). Mongolo-Tungusica, Wiesbaden: Harrassowitz.

DOERFER, G. (2004). Etymologisch-Ethnologisches Wörterbuch tungusischer Dialekte (vornehmlich der Mandschurei), Hildesheim-Zürich-New York: Georg Olms Verlag.

Dyво, A. V. (1997). Nazvanija podarkov v praaltajskom, Honour of the 90th Anniversary of N. A. BASKAKOV, Moscow: Languages of Russian Culture.

FEDotov, M. R. (1996). Etimologičeskij slovar' čuvaškogo jazyka, Tom II: SavYaštaka, Čeboksary: Čuvaškij gosudarstvennyj institut gumanitarnyx nauk.

FORTESCUE, M. (2016). Comparative Nivkh Dictionary, München: LINCOM Europa.

Fortescue, M. J. S. \& L. KaPlan (2001). Comparative Eskimo Dictionary: With Aleut Cognates, Alaska: University of Alaska Press.

GomBocz, Z. (1912). Die bulgarisch-türkische Lehnwörter in der ungarischen Sprache, Helsinki: Suomalais-Ugrilaisen Seuran Toimituksia. 


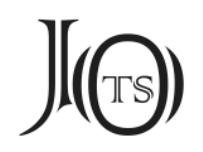

HAENISCH, E. (1939). Wörterbuch zu Mangholun Niuča Tobčaan (Yüanchsao pishi), Geheime Geshichte der Mongolen, Leipzig: Harrassowitz.

Jochelson, W. (1898). “Obrazcy materialov po jukagiskomu jazyku i fol'kloru, sobrannye v Jakutskoj ekspedicii”, Izvestija Imperatorskoj Akademii Nauk, 8: 151-177.

Jochelson, W. (1926). The Yukaghir and the Yukaghirized Tungus, New York: G. E. Stechert American Agents.

KAŁUŻYŃSKI, S. (1961). Mongolische Elemente in der jakutischen Sprache, Warzawa: Państwowe Wydawn.

KAŁUŻYŃSKI, S. (1995). Iautica: Prace językoznawcze, Warszawa: Wydawnictwo Akademickie Dialog.

KozIN, S. A. (1941). Sokrovennoje skazanije, Moscow-Leningrad.

KREjNOVIČ, E. (1958). Jukagirskij jazyk, Moscow: Leningrad: Akademija Nauk.

KREJNOVIČ, E. (1982). Issledovanija i materialy po jukagirskomu jazyku, Leningrad: Nauka.

KuRILOv, G. N. (1990). Jukagirsko-russkij slovar', Akademija Nauk SSSR, Jakutsk: Jakutskoje knizhnoje izdatel'stvo.

KuriLov, G. N. (2001). Jukagirsko-russkij slovar', Rossiskaja Akademija Nauk, Novosibirsk: Sibirskoje otdelenije institut problem malocislennyx narodov severa.

LeHTisalo, T. (1956). Juraksamojedisches Wörterbuch, Helsinki: Suomalais-Ugrilainen Seura.

Lessing, F. D. (1960). Mongolian-English Dictionary, Los Angeles \& Berkeley: University of California Press.

LEWICKI, M. (1949). La langue mongole des transcriptions chinoises du XIV-e siècle, Le Houya-yi yi-yu de 1389, Wroclaw.

LIU (1981). Liu Zhaoxiong. Dongxiang yu jianzhi. Beijing.

LORAND, B. (1967-1976). A magyar nyelv történeti-etimológiai szótára I-IV, Budapest: Akadémiai Kiadó.

MARTIn, S. E. (1987). The Japanese Language through Time, New Haven-London: Yale University Press. 


\section{J(৫)}

MARTIN, S. E. et al. (1967). A Korean-English Dictionary, New Haven-London: Yale University Press.

Maslova, E. (2003). A Grammar of Kolyma Yukaghir, Berlin: Mouton de Gruyter.

MidDENDORFF, A.Th.v. (1851). Über die Sprache der Jakuten, von Otto Böntlingk, Theil 2. Jakutisch-Deutsches Wörterbuch. Reise in den äussersten Norden und Osten Sibiriens Band III, St. Petersburg: Kaiserlichen Akademie der Wissenschaften.

NikolaEaV, S. L. (2015). "Toward the reconstruction of Proto-Algonquian-Wakashan. Part 1: Proof of the Algonquian-Wakashan relationship", Journal of Language Relationship, 13/1: 23-61.

Nikolaeva A. \& V. G. Shalugin (2002). Slovar' Jukagirsko-Russkij i Russkij-Jukagirskij (Verxnekol'mskij Dialekt), St. Petersburg: Izdatel'stvo “Drofa”.

NikolaEVA, I. (2006). A Historical Dictionary of Yukaghir, Berlin \& New York: Mouton de Gruyter.

Nugteren, H. (2011). Mongolic phonology and the Qinghai-Gansu Languages, Utrecht: LOT.

PeKARSKY, E. K. (1959). Slovar jakutskogo jazyka I-III, Akademija Nauk SSSR, Yakutsk.

PIISPANEN, P. S. (2013). "The Uralic-Yukaghiric connection revisited: Sound Correspondences of Geminate Clusters”, Journal de la Société Finno-Ougrienne, 93: 165-197.

PIISPANEN, P. S. (2015). "Evaluating the Uralic-Yukaghiric word-initial, proto-sibilant correspondence rules", Journal de la Société Finno-Ougrienne, 95: 237-273.

PIISPANEN, P. S. (2016a). "Folklore borrowings in north-eastern Siberia", Turkic Languages, 20: 257-272.

PiISPANEN, P. S. (2016b). "A prosody-controlled semi-vowel alternation in Yukaghir", Journal of Historical Linguistics, 6/2: 247-296.

PIISPANEN, P. S. (2017). "Folklore borrowings in north-eastern Siberia”, Turkic Languages, 20: 257-272.

PiISPANEN, P. S. (2018). "Additional Turkic and Tungusic borrowings into Yukaghir”, Turkic Languages, 22: 108-138.

PiISPANEN, P. S. (2019a). "Additional Turkic and Tungusic borrowings into Yukaghir II", Journal of Old Turkic Studies, 3/1: 54-82. 


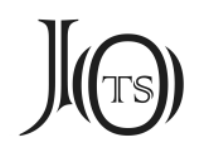

PIISPANEN, P. S. (2019b) “Additional Turkic and Tungusic borrowings into Yukaghir III", Journal of Old Turkic Studies, 3/2: 321-371.

PIISPANEN, P. S. (2019c). "Re-etymologizing Russian cultural vocabulary as mediated by the Yakut", Turkic Languages, 23/2: 222-249.

Poppe, N. (1966). “On some ancient Mongolian loanwords in Tungus”, Central Asiatic Journal, 11/3: 187-198.

RAMSTEDT, G. J. (1935). Kalmückisches Wörterbuch, Helsinki: Suomalais-Ugrilainen Seura.

RÄSÄNEN, M. (1969). Versuch eines etymologisches Wörterbuchs der Türksprachen, Helsinki: Suomalais-Ugrilainen Seura.

RÉDEI, K. (1988-1991). Uralisches etymologisches Wörterbuch, Budapest: Akadémiai Kiadó.

RÉDEI, K. (1999). “Zu den uralisch-jukagirischen Sprachkontakten”, Finnisch-Ugrischen Forschungen, 55: 1-58.

RozYCKI, W. (1994). Mongol Elements in Manchu, Indiana, Bloomington: Research Institute for Inner Asian Studies.

RYвAтZKI, V. (1994). "Bemerkungen zur türkischen und mongolischen Metallterminologie", Studia Orientalia, 73: 193-251.

RYBATZKI, V. (1999). “Turkic words for 'steel' and 'cast iron”, Turkic Languages, 3/1: 56-86.

SANZHEEV, G. D. et al. (2015a). Etimologičeskij slovar' mongol'skix jazykov I: A-E, Moscow: Institut Vostokovedenija RAN.

SANZHEEV, G. D. et al. (2015b). Etimologičeskij slovar' mongol'skix jazykov II: G-P, Moscow: Institut Vostokovedenija RAN.

SEVortjan, E. V. (1974-2000). Ėtimologičeskij slovar' tjurskix jazykov, Moscow.

SLEPCov, P. (1972). Jakutsko-russkij slovar', Moscow: Sovetskaja Ekciklopedija.

SPIRIDONOV, N. I. (2003). Jukagirsko-russkij slovar' i évensko-russkij slovar', Jakutsk: Yakut State University Publishing House.

SPIRIDONOV, V. K. (1997). Shkol'nyj russko-jukagirskij slovar', Jakutsk: Ministerstvo obrazovanija respubliki Saxa (Jakutija). 


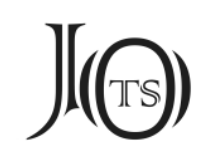

Stachowski, M. (2005). "Chronology of some Yakut phonetic changes in the context of $18^{\text {th }}$ century Mongolian loanwords into Yakut", Rocznik Orientalistyczny, 58: 194-203.

Starostin, S. et al. (2003). An Etymological Dictionary of Altaic Languages I-III, Leiden: Brill.

STARostin, S. et. al. (2003). An Etymological Dictionary of Altaic Languages, Leiden: Brill.

STEINITZ, W. (1966-1993). Dialektologisches und etymologisches Wörterbuch der ostjakischen Sprache (unter Mitarbeit von Liselotte Böhnke Gert Sauer und Brigitte Schulze) I-XV, Berlin: Akademie-Verlag.

TENIŠEv, E. R. (1997). Sravnitel'noistoričeskaja grammatika tjurskix jazykov: Leksika, Moscow: Akademia Nauk.

VASILEVIČ, G. M. (1958). Evenkijsko-Russkij Slovar', Moskva: Gosudarstvennoje isdatel'stvo inostrannyx i natsional'nyx slovarej.

VASILIEV, Y. (1995). Türkçe-Sahaça (Yakutça) Sözlük, Ankara: Türk Dil Kurumu Yayınları.

Vovin, A. (2015). "Eskimo loans in North Tungusic", Iran and the Caucasus, 19: 8795.

WRANGeL, F. von (1841). Putešestvie po severnym beregam Sibiri i po Ledovitomu morju, soveršennoe v 1820, 1821, 1822, 1823 i 1824 godax èkspediciju, sostojavšeju pod načal'stvom flota lejtenanta Ferdinanda fon Vrangelja I-II, St. Petersburg.

YEGoRov, V. G. (1964). Etimologičeskij slovar' čuvaškogo jazyka, Čeboksary. 